Morandi, Matteo

\title{
Long-term issues in secondary school teacher training in Italy (1862-2015)
}

Casale, Rita [Hrsg.]; Windheuser, Jeannette [Hrsg.]; Ferrari, Monica [Hrsg.]; Morandi, Matteo [Hrsg.]: Kulturen der Lehrerbildung in der Sekundarstufe in Italien und Deutschland. Nationale Formate und 'cross culture'. Bad Heilbrunn : Verlag Julius Klinkhardt 2021, S. 51-63. - (Historische Bildungsforschung)

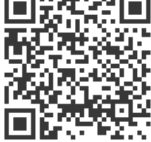

\section{Quellenangabe/ Reference:}

Morandi, Matteo: Long-term issues in secondary school teacher training in Italy (1862-2015) - In: Casale, Rita [Hrsg.]; Windheuser, Jeannette [Hrsg.]; Ferrari, Monica [Hrsg.]; Morandi, Matteo [Hrsg.]: Kulturen der Lehrerbildung in der Sekundarstufe in Italien und Deutschland. Nationale Formate und 'cross culture'. Bad Heilbrunn : Verlag Julius Klinkhardt 2021, S. 51-63 - URN: urn:nbn:de:0111-pedocs-225776 - DOI: 10.25656/01:22577

\section{https://nbn-resolving.org/urn:nbn:de:0111-pedocs-225776}

https://doi.org/10.25656/01:22577

in Kooperation mit / in cooperation with:

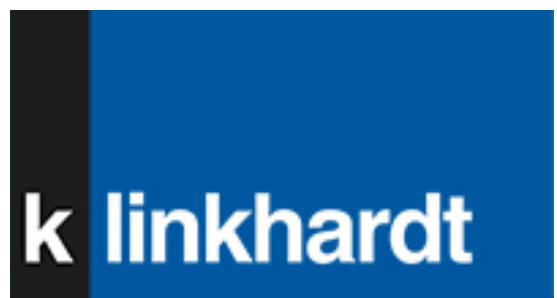

http://www.klinkhardt.de

\section{Nutzungsbedingungen}

Dieses Dokument steht unter folgender Creative Commons-Lizenz: http://creativecommons.org/licenses/by-nc-nd/4.0/deed.de - Sie dürfen das Werk bzw. den Inhalt unter folgenden Bedingungen vervielfältigen, verbreiten und öffentlich zugänglich machen: Sie müssen den Namen des Autors/Rechteinhabers in der von ihm festgelegten Weise nennen. Dieses Werk bzw. dieser Inhalt darf nicht für kommerzielle Zwecke verwendet werden und es darf nicht bearbeitet, abgewandelt oder in anderer Weise verändert werden.

Mit der Verwendung dieses Dokuments erkennen Sie die Nutzungsbedingungen an.

\section{Terms of use}

This document is published under following Creative Commons-License: http://creativecommons.org/licenses/by-nc-nd/4.0/deed.en - You may copy, distribute and transmit, adapt or exhibit the work in the public as long as you attribute the work in the manner specified by the author or licensor. You are not allowed to make commercial use of the work or its contents. You are not allowed to alter, transform, or change this work in any other way.

By using this particular document, you accept the above-stated conditions of use.

\section{Kontakt / Contact:}

\section{peDOCS}

DIPF | Leibniz-Institut für Bildungsforschung und Bildungsinformation Informationszentrum (IZ) Bildung

E-Mail: pedocs@dipf.de

Internet: www.pedocs.de

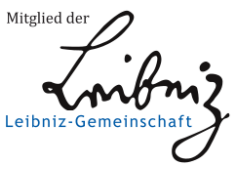




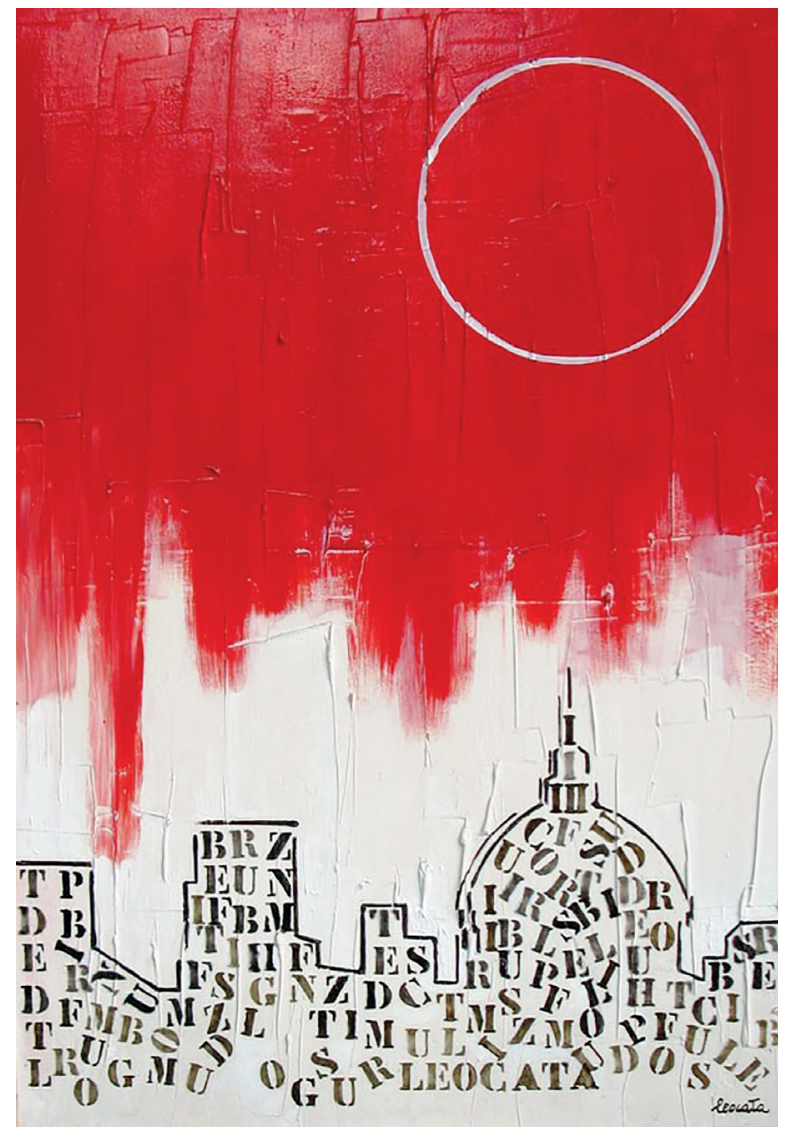

Rita Casale / Jeannette Windheuser Monica Ferrari / Matteo Morandi (Hrsg.)

\section{Kulturen der Lehrerbildung in der Sekundarstufe in Italien und Deutschland}

Nationale Formate und ,cross culture، 
Casale / Windheuser / Ferrari / Morandi

Kulturen der Lehrerbildung in der Sekundarstufe in Italien und Deutschland 


\section{Historische Bildungsforschung}

herausgegeben von

Rita Casale, Ingrid Lohmann und Eva Matthes

\section{In dieser Reihe sind erschienen}

Vogt, Michaela: Professionswissen über Unterstufenschüler in der DDR. Untersuchung der Lehrerzeitschrift „Die Unterstufe“ im Zeitraum 1954 bis 1964. Bad Heilbrunn 2015.

Heinemann, Rebecca: Das Kind als Person. William Stern als Wegbereiter der Kinder- und Jugendforschung 1900 bis 1933. Bad Heilbrunn 2016.

Conrad, Anne/Maier, Alexander (Hrsg.): Erziehung als ,Entfehlerung'. Weltanschauung, Bildung und Geschlecht in der Neuzeit. Bad Heilbrunn 2017.

Müller, Ralf: Die Ordnung der Affekte. Frömmigkeit als Erziehungsideal bei Erasmus von Rotterdam und Philipp Melanchthon. Bad Heilbrunn 2017.

Zimmer, Eva: Wandbilder für die Schulpraxis. Eine historisch-kritische Analyse der Wandbildproduktion des Verlags Schulmann 1925-1987. Bad Heilbrunn 2017.

Horn, Elija: Indien als Erzieher. Orientalismus in der deutschen Reformpädagogik und Jugendbewegung 1918-1933. Bad Heilbrunn 2018.

Haupt, Selma: Das Beharren der Rektoren auf die „Deutsche Universität“. Bad Heilbrunn 2018. Wehren, Sylvia: Erziehung - Körper - Entkörperung. Forschungen zur pädagogischen Theorieentwicklung. Bad Heilbrunn 2020. 


\section{Rita Casale Jeannette Windheuser Monica Ferrari Matteo Morandi \\ (Hrsg.)}

\section{Kulturen der Lehrerbildung in der Sekundarstufe in Italien und Deutschland}

Nationale Formate und ,cross culture 
Der vorliegende Band konnte mithilfe der finanziellen Unterstützung des Lehrstubls für Allgemeine Erziehungswissenschaft / Theorie der Bildung der Bergischen Universität Wuppertal veröffentlicht werden.

Aufgrund einer Vereinbarung zwischen den beiden Verlagen, die die gegenseitige freie Verfügbarkeit der Vertriebsrechte festlegt, erscheint dieser Band zeitgleich in Italien im Verlag FrancoAngeli, herausgegeben von M. Ferrari, M. Morandi, R. Casale und J. Windheuser, unter dem Titel La formazione degli insegnanti della secondaria in Italia e in Germania. Una questione culturale.

Die Herausgeber*innen bedanken sich bei dem Künstler Pippo Leocata für die kostenfreie Überlassung des Titelbildes.

Dieser Titel wurde in das Programm des Verlages mittels eines Peer-Review-Verfahrens aufgenommen. Für weitere Informationen siehe www.klinkhardt.de.

Bibliografische Information der Deutschen Nationalbibliothek Die Deutsche Nationalbibliothek verzeichnet diese Publikation in der Deutschen Nationalbibliografie; detaillierte bibliografische Daten sind im Internet abrufbar über http://dnb.d-nb.de.

2021.lg. ( ) by Julius Klinkhardt.

Grafik Umschlagseite 1: () by Pippo Leocata, La città delle parole [Die Stadt der Worte], Öl und Acryl auf Leinwand, 2014. (Privatsammlung)

Druck und Bindung: Bookstation GmbH, Anzing.

Printed in Germany 2021.

Gedruckt auf chlorfrei gebleichtem alterungsbeständigem Papier.

Die Publikation (mit Ausnahme aller Fotos, Grafiken und Abbildungen) ist veröffentlicht unter der Creative Commons-Lizenz: CC BY-NC-ND 4.0 International https://creativecommons.org/licenses/by-nc-nd/4.0/ 


\section{Inhaltsverzeichnis}

\section{Einführung}

Nationale Fälle und cross culture in der Lehrerbildung

Rita Casale, Monica Ferrari, Matteo Morandi und Jeannette Windheuser .7

\section{Italien}

Habsburg Legislation on the Training of Elementary and Ginnasio-Liceo (Secondary) Teachers and its Implementation in the Italian Territories across the $18^{\text {th }}$ and $19^{\text {th }}$ Centuries

Simonetta Polenghi

The Scuola Normale Superiore di Pisa: between French Model and Autonomous Choices (1810-1923)

Paola Carlucci und Mauro Moretti

Long-Term Issues in Secondary School Teacher Training in Italy

(1862-2015)

Matteo Morandi

Belgium as a Cultural Model for Building the Italian Secondary School and Training its Teachers (1860-1900)

Mara Donato di Paola

An Atypical Path of Women Teachers Training, between the $19^{\text {th }}$ and $20^{\text {th }}$ Centuries: the Istituti Superiori di Magistero femminile

(Higher Institutes of Teaching for Women)

Tiziana Pironi

The Professor of Pedagogy and Italian Textbooks between the $19^{\text {th }}$ and the $20^{\text {th }}$ Centuries

Giuseppe Zago

Pedagogy in the Training Experience of Italian Secondary School Teachers

from SSIS to FIT (and beyond?) (1998-2019)

Monica Ferrari

Training Secondary-School Teachers and the Position of the Minor.

Reflections from a Juridical-Constitutional Perspective

Giuditta Matucci 
The Role of Pedagogy in the Initial Training of Teachers of the Italian Secondary School Today Anna Bondioli, Maurizio Piseri und Donatella Savio

\section{Deutschland}

Seminare - eine hybride Ausbildungsform (18. bis 19. Jahrhundert)

Sabine Reh und Joachim Scholz

Gymnasiallehrer im Vormärz (1830-1848):

Zwischen Wissenschaft und Lehrberuf

Margret Kraul

Geisteswissenschaftliche Pädagogik und

höhere Lehrerausbildung (1915-1960)

Eva Matthes

Modernisierung durch Feminisierung? Zur Geschichte der

Lehrerinnenbildung in Deutschland (19. und frühes 20. Jahrhundert)

Elke Kleinau

Die Lehrerausbildung in der Bundesrepublik seit 1990: die Gründung

der Schools of Education

Charlotte Röhner

Die Entpädagogisierung der Lehrerbildung in der Bundesrepublik und die Entstehung der Bildungswissenschaft als Leitdisziplin in den 1990er Jahren

Rita Casale

Zur Heterogenität des Lehramtsstudiums in Deutschland:

Interaktionsanalysen universitärer Lehrkulturen (21. Jahrhundert)

Imke Kollmer, Hannes König, Thomas Wenzl und Andreas Wernet

Sexuelle Bildung: Geschichtliche und curriculare Perspektiven in der Lehrer/innenbildung

Julia Kerstin Maria Siemoneit und Jeannette Windheuser

Entwicklungen der Lehrerbildung in Deutschland

Jürgen Oelkers 


\title{
Long-Term Issues in Secondary School Teacher Training in Italy (1862-2015)
}

\author{
by Matteo Morandi
}

\begin{abstract}
'In international rankings' - the journalist Salvo Intravaia wrote not long ago in his news report L'Italia che va a scuola - 'children of the Italian primary school are ranked first, while fifteen-year-olds are at the last places. Put simply, teachers of nursery and primary school know the elements of pedagogy and psychology useful to teaching. Colleagues of middle and high school do not'. ${ }^{1}$
\end{abstract}

Without entering into details of a fact that would certainly need to be better explained and historically contextualised, there is no doubt about the acknowledgment, discussed in the quotation cited above, of a psycho-pedagogical acculturation as the foundation of the success (and/or of the effectiveness ${ }^{2}$ ) of the teaching-learning relationship. This holds not only for the primary schools, as per what is now an inveterate tradition, but for schools in general, so also in the 'stronghold' of secondary school. These subjects - expressed in Intravaia's typical impressionist style - are ignored or neglected in teacher training, generally 'pushed into the classrooms without ever having heard of Rousseau or Dewey, let alone taxonomies and didactic units'. ${ }^{3}$

The issue recalls, firstly, the problematic and unresolved question of the relationships between training and education at the schools, i.e. between the independent and autonomous action (assuming it exists) of disciplinary didactics in the classroom and a perspective pertaining to values. ${ }^{4}$ In other words, the tension between a school enclosed within itself (the school at school, as the philosopher of education and teacher Giuseppe Casella would characterise it $)^{5}$ and a school open to the world, with its needs, its stimuli as well as the disposition and existential attitudes of the students towards this world. This seemed to be the case in Italy, especially after the attack by the School of Barbiana against the infamous professoressa and the criticism of the excess of self-referencing that her teaching often represented. ${ }^{6}$

\section{On the concept of teacher professionalisation}

The history of teacher training in the united Italy, all things considered, moves between these two hypotheses: on the one hand, the 'trade' of the high school teacher, just as the elementary school teacher, follows a path of higher education anchored in pedagogy as a professionalising

1 Intravaia 2012, pp. 17ff.

2 This is meant in the sense discussed by the American psychologist Gordon 1974/2013, i.e. the ability of the teacher to establish a dialogical relationship with their students (based on reciprocal respect) in order to promote learning.

On the topic, see also Sclavi/Giornelli 2014.

3 Intravaia 2012, p. 17.

4 See, among others, Massa 1997, pp. 27ff.

5 On Giuseppe Casella, I would like to take the opportunity to refer to Morandi 2015.

6 Cf. Scuola di Barbiana 1967. 
subject. On the other hand, this path coincides with and limits itself to, at least formally speaking, the acquisition of knowledge of the specific subject. 'What if the professional preparation of the teacher were exactly their true, sincere, profound scientific preparation?', ', as Giovanni Gentile had already posed in 1907.

Mind you, it was not really an attempt to de-professionalise the figure of the secondary school teacher, as some have recently contended ${ }^{8}$ and like Gentile might have wanted to do. ${ }^{9}$ It was rather the recognition of the epistemological, meta-formative potential of disciplinary knowledge, perhaps also linked to a limit (or a reluctance) on the part of the university system and teacher training in general when confronted with what Gentile refers to as the 'spontaneous art of the heart ${ }^{\prime},{ }^{10}$ an aesthetic experience (some have recently defined it as erotic) ${ }^{11}$ connected with all professions of care, and thus hardly transmittable by means of institutionalised Bildung.

In opposition to the abstract method of the positivistic imprint, Gentile offers concrete life, 'which has its law in its content'. ${ }^{12}$ The same holds true for the new istituti magistrali, which rose from the ashes of the nineteenth-century normal schools. Apart from the exclusion of psychology and of the internship and the identification of pedagogy with philosophy, the qualifying role these institutes served ended up coinciding with a generic humanistic preparation, which helped to strengthen the relational and communicative skills of the aspiring teachers:

'The candidate, who is preparing for teaching', - recited the exam programmes at the end of the lower course (1923) - 'must prove an organic and firm human knowledge. [...] Excluded, thus, any reciting of half-baked notions, it must be ensured that their studies [...] have interested and struck the soul of the candidate. Great attention will be given to their ability to refer, express themselves clearly, with confidence, to their ease in communicating, main talent of the future teacher. [...] The reading of autobiographic memoirs must be considered as preparation to the study of psychology: not abstract and schematic psychology, but a disposition to understand souls'. ${ }^{13}$

This is the case because idealist pedagogy (think, for example, of Giuseppe Lombardo Radice) contends that real education should never produce a technician, but always a man.

7 Gentile 1988, p. 179.

8 Cf. Causarano 2004, from which I quote, p. 18; see Greci 2007; Saltari 2014, p. 449. Actually, 'traditional teacher professionalism was built [...] around a substantial nucleus of disciplinary knowledge, with the consequence that even common sense up to now has excluded that the practice of teaching could generate in some way any knowledge worth knowing' (Cornacchioli 2002, pp. 189f.).

9 Cf. Brocca 2008, p. 18. Precisely the analysis of professionalisation mechanisms, with specific reference to teacher professionalism - a central issue in the pedagogical debate since the early 2000s, following the institution of the Faculty of Educational Sciences and of the Ssis (1998) - served as the starting point for Egle Becchi and Monica Ferrari to develop the research project Storia pedagogica delle professioni, which has resulted in a series of seven volumes edited by FrancoAngeli between 2009 and 2016. For a theoretical and methodological introduction, see Becchi/Ferrari 2009, specifically p. 8, nt. 4 for a basic bibliography on the topic of educational professionalisms.

10 Reported in Saltari 2014, p. 449.

11 The psychoanalyst Massimo Recalcati interprets the teaching-learning relationship as an erotic transfer towards knowledge, hence the statement 'Nobody can teach teaching, just like, at a fundamental level, nobody can teach learning' (Recalcati 2014, p. 116).

12 Gentile 1988, p. VII.

13 Esame di ammissione alla $1^{a}$ classe del corso superiore dell'istituto magistrale, in Orari e programmi per le regie scuole medie, approved by Royal Decree 14 October 1923, n. 2345 and published in Gazzetta ufficiale del Regno d'Italia, 14 November 1923, n. 267 suppl. (see Santoni Rugiu 1980). 
Mario Gattullo, criticising in the 1980s the ingrained persistence of the model in the school of the Italian Republic, highlighted both the contradictions of not having differentiated the professional goals of future high-school teachers and the complete absence of relational and contextual skills (educational system, docimology, analysis of educational situations, methodology of pedagogical research, etc.), which are necessary to orient the actions of the teacher-professional. In other words, rather than focusing on training, there were a whole series of surrogates (ideological, motivational, experiential) that teachers, at least at the beginning of their career, tended to reproduce. And what they replicated were the styles and patterns of teaching they themselves observed as students, that is, approaches that go back at least one generation. ${ }^{14}$

This happened despite the recruitment mechanism based on the concorso, that took into consideration - at least on paper - for the first time the verification of the knowledge of teachers in secondary schools, 'together with essential specific cultural (and didactic) preparation', of the 'essentials of educational sciences, related to the learners' age and the needs of contemporary society, with particular attention to the problems of the young in and out of school'. ${ }^{15}$ Even if disciplinary knowledge did have specific additional information on the pages of the Gazzetta ufficiale, the same could not be said for those essentials of educational sciences mentioned above.

Even at a time when the reality of recruitment (via concorsi with no prerequisites, titles or even special provisions $)^{16}$ was more confused and much less homogeneous, Pasquale Villari - 100 years before Gattullo and 20 years before Gentile - observed the alleged identification of the professional preparation of the secondary school teacher with the content of knowledge:

'They generally tell themselves: you teach well what you know well [...]. Surely you do not teach well what you know badly; but it is true that you can be a real scientist and a mediocre high school teacher. And many youngsters who would be unable to make scientific discoveries can become good secondary school teachers.

History students (I am speaking about the best ones) study palaeography, medieval law, go to the archive, research sources and conclude their course with a final thesis, which illustrates a certain historical period. Full of passion for their science, they enter high school, without ever having thought about the actual true nature of this school, and the method to use there. They intend to do other jobs and be for now a 'small' university professor, to become as soon as possible a 'great' university professor'. ${ }^{17}$

14 See Gattullo 1985. On the long 'observational apprenticeship' done by teachers when they were students and on the development of a professional collection of 'beliefs' (see Cherubini 1999).

15 Programmi e prove di esame per le classi di concorso a cattedre, a posti di insegnante tecnico-pratico, a posti di insegnante di arte applicata, approved by Ministerial Decree 3 September 1982 and published in Gazzetta ufficiale della Repubblica italiana, 15 October 1982, n. 285 suppl. 2.

16 Cf. Crivellari 2004, pp. 46ff.; see Causarano 2004, pp. 15ff.; Saltari 2014, p. 448 (with some mistakes).

17 Villari 1889, p. 212. According to the same Villari, often young teachers 'have supreme contempt for questions of pure form, and still have not understood how immensely important they are in a high school. They obtained their diploma with honours, presenting a paper on a certain ancient statute of the guild of wool or silk, which they discovered in a library, on the sources of a certain unknown poem, nor can they think about anything else. Time will correct many illusions and finally, if they do not manage to start teaching at university, they too will find their way, and will then become really excellent teachers; but for now their students do not benefit much from them' (Villari 1891, p. 249). 


\section{The failures of pedagogy}

The truth of the matter was that pedagogy had failed to secure a leading role in the national school system during the second half of the nineteenth century. ${ }^{18}$ In their famous La riforma della scuola media of 1908, Alfredo Galletti and Gaetano Salvemini commented that

'A discreet quantity of heroism is necessary to praise it [...]. The clumsiness, the impudence, the presumptuous lightheartedness of many pedagogists has covered pedagogy in ridicule among us and elsewhere $[. .$.$] . The pedagogist is, at least five times out of ten, a scoundrel that knows nothing about$ anything, and expects to teach everyone how to teach everything'.

However, the two scholars continued:

'[W] believe that, with the broadest doctrine and the best philosophical preparation and the most seraphic goodness of this world, the person who enters school will become a good teacher without ever having asked themselves what social class the students they will have to educate belong to; what the pupils of that given social class have the right to expect from the State school and what the State has the duty to ask of them'? ${ }^{19}$

Whether it was an invitation to follow - or at the very least to understand - the profound transformations of Italian society at the height of liberalism in the post-unity era, as Galletti and Salvemini both asked within the National Federation of Middle School Teachers, ${ }^{20}$ or an actual 'praise of practice', as Gentile urged, the idea always advocated the discarding of any sort of pedagogical abstractionism, and with it rejecting the attempts that had been made up to that point to give academic and vocational dignity to pedagogy, in the varied and confused context of a graduate, post-graduate or para-university, training of the middle-school teacher. Ferrante Aporti, an Austrian official in the field of public schooling and founder of the first nursery school in Cremona (1828), opened the first method school at the University of Turin in 1844. It was the first of its kind in Italy ${ }^{21}$ and the precursor to higher education teacher training programmes (for the training of trainers at a peripheral level). Core subjects included general didactics ('having to consider the faculties of the human brain, and the way in which these operate in children, [the course] will be based on the more certain observations administered by experience, rather than wandering in abstract discussions'), 'special' subject didactics, the 'duties of the method teacher' and finally the 'principles of school discipline'.22

At about the same time in Pisa, the 'theoretical and practical' Scuola Normale opened in 1847. Modelled on the previous Napoleonic institute founded in 1810 as a branch of the Normale of Paris, it offered secondary school preparation for teachers. During the commencement speech held when the school first opened, the professor of pedagogy Gaspero Pecchioli stated that:

'some men come to this earth only to meditate, others only to work; and so if these are left where nature has placed them, they feel at ease, and they can do great things: but if you change their place,

18 Cf. Santoni Rugiu 1959, p. 189. On the same issue, see Giuseppe Zago's contribution in this volume and Genovesi 1978 .

19 Galletti/Salvemini 1908, pp. 405 f.

20 See Ambrosoli 1967.

21 See Fornaca 1998. On the influence of the Habsburg model in the Reign of Sardinia through Aporti, see Simonetta Polenghi's contribution in this volume and Bianchini 2012.

22 Royal Patent Letters 1 August 1845, in Raccolta degli atti del governo di S.M. il Re di Sardegna, Torino 1845, pp. 283ff. 
they stumble and fail. Rare are those men who have both these things within them, and can do both. Yet education would want to be given only to these few. ${ }^{23}$

In such a brief excursus, I will not bother to touch upon the evolution and contradictions of the teacher-training model proposed by the Tuscan Scuola Normale, which is already the subject of a contribution in this volume. I will state only that the dominant logic in Pisa since 1862, when the post-unity reorganisation of the Scuola took place - one that its ex-student Gentile completely embraced - did not advocate training all of the teachers of the Kingdom's secondary schools, but only an elite, i.e. a certain number of excellent teachers. As such, were addressed exclusively those of the liceo.

The events related to the training of secondary school teachers present, both prior to and after the unity, an extremely varied series of situations, not always easily definable, with the consequent introduction of 'inept people in the noble arena of teachers'. ${ }^{24}$ At the same time, or shortly before, other projects started, such as Cattaneo's 'professor faculty' (Milan 1848) ${ }^{25}$ or De Sanctis's normal schools modelled after Pisa (1862), ${ }^{26}$ which focused specifically on training teachers. While the choice of 'special' institutes, as an alternative or parallel path to the ordinary university track (high normal schools), seemed to characterise Italian politics for quite some time, it soon gave way to broader interventions aimed at modifying the entire national university system, with the intention of making it more professional. Alongside the Normale of Pisa, the qualification to become a secondary school teacher was also offered by the Scientific-Literary Academy of Milan, founded in 1859 as an institute of higher education akin to a university faculty of Philosophy and Letters, ${ }^{27}$ the philosophical-philological section of the Istituto Superiore of Florence, the philological-historical seminar of the University of Padua and finally the Scuola Normale Superiore established at the University of Naples in 1869. ${ }^{28}$ Around this time, normal courses for teachers of technical-scientific subjects were started to be offered at the Italian Industrial Museum of Turin and the Polytechnic of Milan; ${ }^{29}$ moreover, on 9 October 1873, per Royal Decree, the Application School for engineers, which was attached to the scientific faculty of the University of Rome, was reorganised with a specific section for aspiring teachers of mathematics, physics, chemistry and natural history in the kingdom's technical institutes.

Generally speaking, these differed little from faculties, they were arid pedagogically and poorly defined in their didactic content, ${ }^{30}$ if not for the emphasis placed on a rigid and abstract methodology which came to characterise, for better or for worse, the entire sixty years following national unification. Notable exceptions were the teaching subject associations, such as Mathe-

23 Pecchioli 1847, p. 13. On the Scuola Normale of Pisa, along with the contribution of P. Carlucci and M. Moretti in this volume, see Tomasi/Sistoli Paoli 1990, Carlucci 2010, Moretti 2011 (all with previous bibliography).

24 Sulle condizioni della pubblica istruzione nel Regno d'Italia. Relazione generale presentata al Ministro dal Consiglio Superiore di Torino, Milano 1865, p. 248.

25 Cattaneo 1851.

26 A bill presented at the Senate in the session 1 February 1862, in Atti parlamentari, Senato del Regno, Documenti, VIII term, session 1861, n. 115.

27 For the origins of the Milan Academy, see Decleva 2001. On the Florentine Institute, Rogari 1991, Rogari 1998 and Soldani 2016.

28 See Nuovo codice della istruzione pubblica. Raccolta delle leggi, decreti, regolamenti, circolari, istruzioni e decisioni ministeriali [...], Saluzzo 1870, p. 201, nt. 1 (see Moretti 2011, pp. 29ff.).

29 Cf. Scoth 1980, pp. 94 f., with previous bibliography.

30 Cf. Santoni Rugiu 1959, p. 198. The teaching schools established at the various universities have scarcely been studied with respect to their aims and outcomes, in part due to the absence of a significant apparatus of sources. 
sis (1895), ${ }^{31}$ which were committed to perfecting not only content but also methodologies as the means to improve professional performance. The scuole di magistero (teaching schools) that were instituted in 1875 (Royal Decrees 11 October, nn. 2742 and 2743) within the faculty of Science and Letters ${ }^{32}$ as additional, non-mandatory courses that took place parallel to the standard curricular plans, 'even where they exist, they [are] only illusion', noted in 1882 Saverio De Dominicis (among the greatest proponents in Italy of a conversion of pedagogy into practical knowledge directly applicable in classrooms). According to De Dominicis, this situation is regrettable:

'[I]t is the Teaching School, not the Faculties, which can make good teachers; the Faculty has made and will always make some youngsters erudite: but erudite youngsters are not teachers. The Teaching School should come after the Faculty studies and not be of this or that Faculty, but the Teaching School for secondary school teaching.... School which would force teachers to ponder pedagogical problems and to be able to comprehend the unity of the educational process of our secondary schools'. ${ }^{33}$

The primary impediment to the success of the government's plan was the fact that the teaching staff responsible for the ordinary courses, often lacking didactic experience acquired in secondary schools and not particularly interested in modifying their teaching practices, also taught within the context of the new programme. This hindered the development of the programme to such an extent that Minister Pasquale Villari in 1891 (Royal Decree 29 November, n. 711) stressed that both general and subject didactics in teaching schools should have been in the first case given exclusively to teachers 'who have vast practical experience in secondary school teaching', in the second case preferably to the same.

At the beginning of the century, just as the so-called 'pedagogical schools', i.e. the two-year specialised training courses for primary school teachers working toward a managerial or supervisor careers (1905-1923), ${ }^{34}$ were forming and pedagogy was finally starting to establish itself, thanks primarily to Herbart's thought, ${ }^{35}$ as an academic subject applicable to everyday school experiences the rise of idealism ruined in a single stroke an institution built on unstable ground. The logic of teaching schools was of a continuous draining of content and meaning. The Royal Decree of 8 October 1920, n. 1546 issued by the philosopher Benedetto Croce, who served as Minister of Public Education in Giolitti's last cabinet, effectively brought an end to these schools by substituting them ${ }^{36}$ with tutorial courses at universities and high schools. This marked a new chapter in the history of teacher training (mainly, but not exclusively, for high school teachers). As Simonetta Ulivieri wrote, these schools are 'cut off from the social fabric that express[ed] it', insensitive towards the 'affective-relational problems, or [of] the

31 Regarding Mathesis, please refer to the publication integrally reported at the following address http://www.mathesisnazionale.it/storia/, 02.07.2020. Further, Ambrisi 2015.

32 But not in the other faculties or high schools also offering preparation for secondary school teaching, such as law, languages and commerce high schools.

33 Quoted by Santoni Rugiu 1959, p. 136. On the De Dominicis' teaching in Pavia, see in particular Becchi 1991, Becchi 1995 and also Morandi 2017.

34 Royal Decrees 19 January 1905, n. 29 and 1 February 1906, n. 30. On this topic, the monographic sections have been dedicated of two issues of the Annali di storia dell'educazione e delle istituzioni scolastiche 10 (2003) and 11 (2004).

35 On Italian Herbartism at the beginning of the century, see Meschiari 1980 and especially Volpicelli 2003.

36 See Nastasi 2002 (who provides the incorrect date of the Decree of suppression). On Croce minister, see Tognon 1990. 
marked socio-economic hardship of its pupils'. She continues stating that they are almost proud of 'sharing equally among unequals' and, to quote Father Milani, 'looking only at assessment, at profit'. ${ }^{37}$

\section{New world, original curricula: towards a questioning of the disciplinary model}

After the Second World War, a time in which idealism was starting to wane, the contradictions between ancient and modern, authority and democracy manifested themselves on the didactic level in two alternative positions: between 'the old model of the instructor who taught one or more subjects and so [...] was an impartial judge of what the individual students had actually learned' and that of the teacher

'who, together with colleagues, participates in the mental and moral development of the students, which assumed, besides a new didactic methodology for the traditional subjects, first of all, a predisposition towards behaviours and knowledge of techniques that nobody had ever offered the teachers or which nobody had taken into account at the time of their recruitment at school'. ${ }^{38}$

The recruitment of teaching staff resumed in 1947, and it was now based on very strict tests that were regulated by a 1932 Decree (Royal Decree 27 October, n. 1489). The programmes required an extremely broad subject preparation, 'almost sceptically wanting to verify if the candidates, through this preparation, had bridged the gaps they had surely accumulated during their university studies' ${ }^{39}$

Another turning point was the reform of middle schools in 1962 (Law 31 December, n. 1859). In addition to the traditional teachings and educational roles, this reform included new activities and original curricula, which were both addressed to an even wider audience (the masses) and was above all more heterogeneous socially and culturally speaking. Aldo Agazzi wrote that in the wake of the reform, for example, that teachers instructing first-level secondary school mathematics

'must also teach observations and notions of physics and natural science (with relative method and content problems); teachers of drawing must promote an artistic education of taste and execution in the field of visual arts (drawing, painting, plastic and handcraft minor arts). [...] The teacher of technical applications, abandoned the elementarism with its precocius nature, which therefore makes the exercises typical of most of the ex-professional training schools an automated task, with no reasoning, must promote executions of school work as 'reasoned action" ${ }^{40}$

The reform programmes of 1979 (Ministerial Decree 9 February, for the middle school) and later 1982 (Decree of the President of the Republic 1 October, n. 908, for secondary schools) assigned physical education teachers a kind of 'super-teacher' status. They were now expected to supervise or watch over the entire educational path of their students.

37 Ulivieri 2006, p. 42, and Ulivieri 2012. Moreover, Causarano 2004 and Greci 2007.

38 Santoni Rugiu 2009, p. 44.

39 Crivellari 2004, p. 47. See also Berardi 2001, pp. $35 \mathrm{ff}$.

40 Agazzi 1964, p. 27. 
'The educational relationship that is established between the student and physical education teacher' - I am quoting from the 1982 text - 'makes the latter the 'adult' to whom the adolescent more frequently confides in asking for advice; so the physical education teacher often has greater opportunities to shed light, within the context of staff meetings, on aspects, even if transitory, of the students' personality, which would otherwise escape proper considerations. ${ }^{41}$

While the recruitment process continued to rely on programmes with a tremendous amount of content, the didactic openness towards new tools and teaching aids, especially audio-visual media, was still quite timid. ${ }^{42}$ For a school system that was less and less self-referential after the 1970s, that was developed 'from the bottom up', ${ }^{43}$ and with a heterogeneous and complex system undergoing rapid change, in which the political demands assigned new and unexpected duties to teachers, oriented towards a renewed concept of citizenship (road safety, sex, health, food education, and so on), ${ }^{44}$ what form of preparation was to be considered essential? To the pedagogical skills that were considered essential for the coherent orientation of educational action, other subjects such as psychological, sociological and didactic skills were also added, without overlapping with the training in the specific subjects. This was all happening because secondary schools were starting to be interpreted and lived as a 'place of an educational nature', i.e. a 'biographically valid experience for a stage of life in which, besides being itself full of problems, is the prelude to a moment of personal experience which surely cannot be described as simple'. ${ }^{45}$ This need for change, which did not produce, despite several important parliamentary proposals, organic and definitive regulatory outcomes, not to mention in the absence of a general reform of the secondary level, ${ }^{46}$ was spearheaded by professors of pedagogy such as Mario Gattullo, Aldo Visalberghi and Maria Corda Costa, educational psychologists such as Clotilde Pontecorvo, and subject specialists like the mathematician (not by accident, given the didactic tradition in this sense!) Giunio Luzzatto.

\section{The ideal type of the reflective teacher}

It was only with the law that reformed the university system (19 November 1990, n. 341) that the preparation of future teachers, a task previously entrusted to the universities, was given to postgraduate specialisation schools (Ssis), which were finally up and running almost a decade later, in 1998 (Ministerial Decree 26 May). ${ }^{47}$ These specialisation schools remained active until the 2008-2009 academic year and were later substituted by two cycles of Tfa (Tirocinio formativo attivo - Active Apprenticeship, starting from the academic year 2011-2012) and by the Pas (Percorsi abilitanti speciali - Special Qualifying Training, academic year 2013-2014).

41 See Morandi 2016. On the topic, see also Ferrari 2016, p. 88.

42 See Regolamento per lo svolgimento degli esami di Stato per l'abilitazione all'esercizio professionale dell'insegnamento nella scuola media [...], approved by Decree of the President of the Republic 21 November 1966, n. 1298 and published in Gazzetta ufficiale della Repubblica italiana, 13 February 1967, n. 39.

43 Ulivieri 2006, p. 47.

44 For example, Programmi di educazione stradale, approved by Ministerial Decree 5 August 1994 and published in Gazzetta ufficiale della Repubblica italiana, 19 August 1994, n. 193. On the concept of 'education to', see Audigier 2012 and Audigier 2014.

45 Scurati 1997.

46 Cf. Luzzatto 1999, pp. $17 \mathrm{ff}$.

47 See Curti 2000. 
What emerged from many quarters was the need for a pedagogical path capable of mediating between scientific subject knowledge and practical knowledge, ${ }^{48}$ while also in Italy, thanks the abovementioned Ssis, the acquisitions of scholars of the school and the school curriculum were arriving, according to whom among the teacher's and students' desks culture was not only transmitted, but also produced. ${ }^{49}$

According to the debate that took place within these specialisation schools, ${ }^{50}$ the ideal they hoped to achieve was the reflective teacher who, following the works of Donald Schön, who in turn owed a great deal to Dewey, ${ }^{51}$ was able both during and after the action to obtain a de-centred perspective with regards to their professional practice. In other words, they would be able to make it an object of reflection and study with a view to solving problems and re-thinking what had actually occurred, also in terms of formative and transformative evaluation. ${ }^{52}$ 'Observing, diagnosing, making decisions and devising educational-didactic intervention projects, using resources appropriately', Giovacchino Petracchi wrote, 'are operations that enhance the evaluation function'. ${ }^{3}$

Assessment, evaluation of context, of the teacher professionalism and of the whole school system: 'reflectivity' as a central aspect of the training of educational professionals ran parallel to and sometimes intertwined (in Italy as well as part of Ssis' didactic training) with such matters, while at the same time a national evaluation system throughout Italy was being established, which promoted practices via the school evaluation that were not always completely in line with this debate. ${ }^{54}$

At the end of an admittedly very fragmented overview, which is itself only an introduction to a topic that warrants further detailed studies, the Foucauldian perspective of the 'diagnostic' school (the hierarchy that oversees and the sanction that normalises) as the place where pedagogy is processed has been overturned (or perhaps it is a continuation under another species). 'As the hospital exam procedure allows the epistemological rupture of medicine, the era of the 'examining' school marks the beginning of a pedagogy that works as a science'. ${ }^{55}$ Let us ask ourselves, then, if this has really been the direction imparted by the experts' debate, both in Italy and abroad. Or is all of this actually the result of the cultural and political circumstances of a school system that has, after the closure of the Ssis, repeatedly faltered in recent years, and which has been unable to incentivise operations of pedagogical analysis, both reflective and evaluative, of the experiences of teacher training promoted by Decree.

48 See Altet/Charlier/Paquay/Perrenoud 2006.

49 Reference to Chervel 1998 should be made here, as well as to Julia 1995. For a historiographical review on England, France and Spain, see Viñao 2010; for Italy, Bianchini 2010.

50 For a review of the literature in this sense - where, albeit with different inflections, a reflexive approach prevails (see Ferrari 2011). Also, see Ferrari's contribution in this volume. Several magazines specifically dedicated to the Ssis were established in those years (for example, Didatticamente. La voce della Ssis, Tuscany), and these published essays on the topic of teacher reflectivity, which at that time was at the centre of didactic practice in training teachers in a great number of contexts.

51 See Schön 1983/1993, Schön 1987/2006.

52 Significant in this regard is the path established by the pedagogical teachings of the University of Pavia. For more on this, see Ferrari 2003, Gusmini 2004, Ferrari 2006, Bondioli/Ferrari/Marsilio/Tacchini 2006, Bondioli 2012. Generally speaking, the bibliography on the reflective teacher is substantial in Italy and beyond: with regard to the Italian case dealt with here, see Striano 2001 and Fabbri/Striano/Melacarne 2008.

53 Petracchi 1989.

54 See Ferrari/Morandi/Falanga 2018.

55 Foucault 1975/1976, p. 204. 


\section{Sources and Literature}

\section{Published Sources}

1845: Royal Patent Letters 1 August. In: Raccolta degli atti del governo di S.M. il Re di Sardegna, Torino 1845, pp. $283 \mathrm{ff}$.

1861: Atti parlamentari, Senato del Regno, Documenti, VIII term, n. 115.

1865: Sulle condizioni della pubblica istruzione nel Regno d'Italia. Relazione generale presentata al Ministro dal Consiglio Superiore di Torino. Milano.

1870: Nuovo codice della istruzione pubblica. Raccolta delle leggi, decreti, regolamenti, circolari, istruzioni e decisioni ministeriali [...], Saluzzo.

1873: Regolamento organico della Scuola d'applicazione per gli ingegneri in Roma, approved by Royal Decree 9 October, n. 1612. In: Gazzetta ufficiale del Regno d'Italia, 27 October 1873, n. 297.

1875: Regolamento per la Facoltà di Scienze matematiche, fisiche e naturali, approved by Royal Decree 11 October, n. 2742. In: Gazzetta ufficiale del Regno d'Italia, 2 November 1875, n. 255.

1875: Regolamento per la Facoltà di Filosofia e Lettere, approved by Royal Decree 11 October, n. 2743. In: Gazzetta ufficiale del Regno d'Italia, 3 November 1875, n. 256.

1891: Regolamento per le Scuole di magistero, approved by Royal Decree 29 November, n. 711. In: Gazzetta ufficiale del Regno d'Italia, 9 January 1892, n. 6.

1905: Royal Decree 19 January, n. 29. In: Gazzetta ufficiale del Regno d'Italia, 23 February 1905, n. 45.

1906: Royal Decree 1 February, n. 30. In: Gazzetta ufficiale del Regno d'Italia, 21 February 1906, n. 43.

1920: Royal Decree 8 October, n. 1546. In: Gazzetta ufficiale del Regno d'Italia, 16 November 1920, n. 270.

1923: Orari e programmi per le regie scuole medie, approved by Royal Decree 14 October, n. 2345. In: Gazzetta ufficiale del Regno d'Italia, 14 November 1923, n. 267 suppl.

1932: Programmi per i concorsi a cattedre nei regi istituti medi d'istruzione e per le abilitazioni all'esercizio professionale dell'insegnamento medio, approved by Royal Decree 27 October, n. 1489. In: Gazzetta ufficiale del Regno d'Italia, 29 November 1932, n. 275.

1962: Law 31 December, n. 1859. In: Gazzetta ufficiale della Repubblica italiana, 30 January 1963, n. 27.

1966: Regolamento per lo svolgimento degli esami di Stato per l'abilitazione all'esercizio professionale dell'insegnamento nella scuola media [...], approved by Decree of the President of the Republic 21 November, n. 1298. In: Gazzetta ufficiale della Repubblica italiana, 13 February 1967, n. 39.

1979: Nuovi programmi, orari d'insegnamento e prove d'esame per la scuola media, approved by Ministerial Decree 9 February. In: Gazzetta ufficiale della Repubblica italiana, 20 February 1979, n. 50 suppl.

1982: Nuovi programmi d'insegnamento di educazione fisica negli istituti d'istruzione secondaria superiore, nei licei artistici e negli istituti d'arte, approved by Decree of the President of the Republic 1 October, n. 908. In: Gazzetta ufficiale della Repubblica italiana, 9 December 1982, n. 337.

1982: Programmi e prove di esame per le classi di concorso a cattedre, a posti di insegnante tecnico-pratico, a posti di insegnante di arte applicata, approved by Ministerial Decree 3 September. In: Gazzetta ufficiale della Repubblica italiana, 15 October 1982, n. 285 suppl. 2.

1994: Programmi di educazione stradale, approved by Ministerial Decree 5 August. In: Gazzetta ufficiale della Repubblica italiana, 19 August 1994, n. 193.

1998: Ministerial Decree 26 May. In: Gazzetta ufficiale della Repubblica italiana, 7 March 1998, n. 153.

\section{Literature}

Agazzi, Aldo (with the Collaboration of Zavalloni, Roberto et al.) (ed.) (1964): La formazione degli insegnanti. Bari. Altet, Marguerite/Charlier, Eveline/Paquay, Leopold/Perrenoud, Philippe (1994/2006): Formare gli insegnanti professionisti. Quali strategie? Quali competenze? Roma.

Ambrisi, Emilio (2015): I 120 anni della Mathesis. La storia dell'insegnamento e dell'apprendimento della matematica in Italia e la situazione attuale. Roma.

Ambrosoli, Luigi (1967): La Federazione Nazionale Insegnanti Scuola Media dalle origini al 1925. Firenze.

Audigier, François (2012): Les Éducations à...et la formation au monde social. In: Recherches en didactiques 14, pp. 47-63. https://www.cairn.info/revue-recherches-en-didactiques-2012-2-page-47.htm, 02.07.2020.

Audigier, François (2014): L'educazione a... Quali significati e quali implicazioni teoriche e pratiche? Tracce per un'analisi. In: Scuola ticinese 319, pp. 12-19. https://edudoc.ch/record/113669?/n=de, 02.07.2020.

Becchi, Egle (1991): Francesco Saverio De Dominicis all'Università di Pavia: 1881-1920. In: Bollettino della Società pavese di storia patria 91, 43, pp. 301-311. 
Becchi, Egle (1995): Studiar pedagogia all'Ateneo pavese durante il magistero di De Dominicis (1880-1920). In: Annali di storia pavese 22-23, pp. 399-404.

Becchi, Egle/Ferrari, Monica (2009): Professioni, professionisti, professionalizzare: storie di formazione. In: Eaed. (eds.): Formare alle professioni. Sacerdoti, principi, educatori. Milano, pp. 7-27.

Berardi, Roberto (2001): La scuola nella prima Repubblica. Dai taccuini di un ispettore centrale. Roma.

Bianchini, Paolo (ed.) (2010): Le origini delle materie. Discipline, programmi e manuali scolastici in Italia. Torino.

Bianchini, Paolo (2012): La ricezione della pedagogia austro-lombarda nel Piemonte sabaudo. In: Polenghi, Simonetta (ed.): La scuola degli Asburgo. Pedagogia e formazione degli insegnanti tra il Danubio e il Po (1773-1918). Torino, pp. 91-113.

Bondioli, Anna (2012): La formazione degli insegnanti come problema. In: Bevilacqua, Fabio/Contardini, Patrizia (eds.): Storia, Didattica, Scienze. Pavia 1975-2010. Conference proceedings (Pavia, 7 May 2010). Pavia, pp. 9-19.

Bondioli, Anna/Ferrari, Monica/Marsilio, Marina/Tacchini, Isabella (eds.) (2006): I saperi del tirocinio. Formare gli insegnanti nelle SSIS. Milano.

Brocca, Beniamino (2008): Le ali e i carrelli. Della professione docente. Roma.

Carlucci, Paola (2010): La Scuola Normale Superiore. Percorsi del merito 1810-2010. Pisa.

Cattaneo, Carlo (1851): Sull'ulteriore sviluppo del pubblico insegnamento in Lombardia. In: L'Educatore 2, pp. $30-94$.

Causarano, Pietro (2004): La formazione e l'aggiornamento degli insegnanti secondari nell'Italia repubblicana: una prima ricognizione. In: Bosco, Giuseppe/Mantovani, Claudia (eds.): La storia contemporanea tra scuola e università. Manuali, programmi, docenti. Soveria Mannelli, pp. 177-200.

Cherubini, Giorgio (1999): Il ruolo delle conoscenze pratiche e delle credenze nello sviluppo professionale degli insegnanti. In: Zambelli, Franco/Cherubini, Giorgio (eds.): Manuale della scuola dell'obbligo: l'insegnante e i suoi contesti. Milano, pp. 29-66.

Chervel, André (1998): La culture scolaire. Une approche historique. Paris.

Cornacchioli, Tobia (2002): Lineamenti di didattica della storia. Dal sapere storico alla storia insegnata: la mediazione didattica, preface by D'Agostino, Guido. Cosenza.

Crivellari, Claudio (2004): Professori nella scuola di massa. Dalla crisi del ruolo alla formazione universitaria. Roma.

Curti, Luca (2000): Le Scuole di specializzazione nell'insegnamento secondario (Ssis). Storia, problemi, prospettive. In: Il Mestiere di storico 1. http://www.sissco.it/articoli/annale-i2000-1053/le-scuole-di-specializzazione-per-linsegnamento-superiore-1066/le-scuole-di-specializzazione-nellinsegnamento-secondario-ssis-storia-problemi-prospettive-1067, 02.07.2020.

Decleva, Enrico (2001): Una facoltà filosofico-letteraria nella città industriale alla ricerca di un'identità (1861-1881). In: Barbarisi, Gennaro/Decleva, Enrico/Morgana, Silvia (eds.): Milano e l'Accademia scientifico-letteraria. Studi in onore di Maurizio Vitale. Milano, pp. 3-196.

Fabbri, Loretta/Striano, Maura/ Melacarne, Claudio (2008): L'insegnante riflessivo. Coltivazione e trasformazione delle pratiche professionali. Milano.

Ferrari, Monica (ed.) (2003): Insegnare riflettendo. Proposte pedagogiche per i docenti della secondaria. Milano.

Ferrari, Monica (2006): Pratiche riflessive nei processi formativi dei formatori. In: Didatticamente. La voce della Ssis1-2, pp. 45-63.

Ferrari, Monica (ed.) (2011): VAL-SILSIS (PV). Strumenti di valutazione elaborati dalla SILSIS, sezione di Pavia. Pavia.

Ferrari, Monica (2016): I 'programmi' italiani di educazione fisica: contesti e attori. In: Morandi, Matteo (ed.), Corpo, educazione fisica, sport. Questioni pedagogiche. Milano, pp. 72-92.

Ferrari, Monica/Morandi, Matteo/Falanga, Mario (2018): Valutazione scolastica. Il concetto, la storia, la norma. Brescia.

Fornaca, Remo (1998): L'Università di Torino e l'inizio dei corsi di metodica. In: Dipartimento di Scienze dell'educazione dell'Università degli studi di Torino: Dalla metodica alle scienze dell'educazione. 150 anni di insegnamenti pedagogici nell'Università di Torino. Torino, pp. 57-87.

Foucault, Michel (1975/1976): Sorvegliare e punire. Nascita della prigione. Torino.

Galletti, Alfredo/Salvemini, Gaetano (1908): La riforma della scuola media. Notizie, osservazioni, proposte. Milano.

Gattullo, Mario (1985): Sul profilo professionale dell'insegnante. In: Scuola e città 36, 7, pp. 288-302.

Genovesi, Giovanni (1978): I professori. In: Tomasi, Tina et al. (eds.): La scuola secondaria in Italia (1859-1977). Firenze, pp. 33-87.

Gentile, Giovanni (1988): La nuova scuola media, edited by Cavallera, Hervé Antonio, Firenze.

Gordon, Thomas (1974/2013): Insegnanti efficaci. Pratiche educative per insegnanti, genitori e studenti. Firenze. 
Greci, Roberto (2007): Università e formazione degli insegnanti. In: Annali di storia delle università italiane 11, pp. 9-29.

Gusmini, Maria Paola (2004): Riflettere. In: Bondioli, Anna/Ferrari, Monica (eds.): Verso un modello di valutazione formativa. Ragioni, strumenti e percorsi. Azzano San Paolo, pp. 93-143.

Intravaia, Salvo (2012): L'Italia che va a scuola. Roma-Bari.

Julia, Dominique (1995): La culture scolaire comme objet historique. In: Paedagogica Historica, Supplementary Series, 1: Nóvoa, Antonio/Depaepe, Marc/Johanningmeier, Erwin V. (eds.): The Colonial Experience in Education. Historical Issues and Perspectives, pp. 353-382.

Le scuole pedagogiche (2003 and 2004). Monographic Sections in: Annali di storia dell'educazione e delle istituzioni scolastiche 10, pp. 9-288 and 11, pp. 185-321.

Luzzatto, Giunio (1999): Insegnare a insegnare. I nuovi corsi universitari per la formazione dei docenti. Roma.

Massa, Riccardo (1997): Cambiare la scuola. Educare o istruire? Roma-Bari.

Meschiari, Alberto (1980): Per una storia dell'herbartismo in Italia. In: Rivista di filosofia 16, pp. 98-124.

Morandi, Matteo (2015): Sub imperio veritatis. Giuseppe Casella filosofo dell'educazione e uomo di scuola. In: Annali di storia dell'educazione e delle istituzioni scolastiche 22, pp. 206-223.

Morandi, Matteo (2016): Snodi identitari di una materia scolastica. In: Id. (ed.): Corpo, educazione fisica, sport. Questioni pedagogiche. Milano, pp. 56-71.

Morandi, Matteo (2017): Saverio De Dominicis e l'insegnamento della Pedagogia. In: Mantovani, Dario (ed.): Almum Studium Papiense. Storia dell'Università di Pavia. Vol. 2/2: Dalla Restaurazione alla Grande guerra. Milano, pp. 1275-1276.

Moretti, Mauro (2011): Toscana, Italia, Europa: la Normale di Pisa e i modelli universitari fra Otto e Novecento. In: Annali della Scuola normale superiore di Pisa. Classe di Lettere e Filosofia s. V, 3/1: Il futuro di una tradizione: formazione d'eccellenza nell'Europa contemporanea, pp. 11-33.

Nastasi, Pietro (2002): La Mathesis e il problema della formazione degli insegnanti. In: Bolondi, Giorgio (ed.): La Mathesis. La prima metà del Novecento nella 'Società italiana di Scienze matematiche e fisiche'. Milano, pp. 59-119.

Pecchioli, Gaspero (1847): Orazione letta nella solenne apertura della Regia Scuola Normale a dì 15 Novembre 1847. Pisa.

Petracchi, Giovacchino (1989): Insegnanti, formazione degli. In: Laeng, Mauro (ed.): Enciclopedia pedagogica. Vol. 3. Brescia, coll. 6075-6079.

Recalcati, Massimo (2014): L’ora di lezione. Per un'erotica dell'insegnamento. Torino.

Rogari, Sandro (1991): L'Istituto di studi superiori pratici e di perfezionamento e la Scuola di scienze sociali (18591924). In: Id.: Cultura e istruzione superiore a Firenze. Dall'Unità alla grande guerra. Firenze, pp. 27-99.

Rogari, Sandro (1998): L'Istituto di studi superiori pratici e di perfezionamento, la Scuola di Scienze sociali e le Università toscane. In: Brizzi, Gian Paolo/Verger, Jacques (eds.): Le Università minori in Europa (secoli XV-XIX). Soveria Mannelli, pp. 579-594.

Saltari, Lorenzo (2014): La formazione e il reclutamento degli insegnanti in Italia. In: Rivista trimestrale di diritto pubblico 2, pp. 444-475.

Santoni Rugiu, Antonio (1959): Il professore nella scuola italiana. Firenze.

Santoni Rugiu, Antonio (1980): Ideologia e programmi nelle scuole elementari e magistrali dal 1859 al 1955 . Firenze.

Santoni Rugiu, Antonio (2009): Un maestro d'utopia. In: Betti, Carmen (ed.): Don Milani fra storia e memoria. La sua eredità quarant'anni dopo. Milano, pp. 39-50.

Schön, Donald A. (1983/1993): Il professionista riflessivo. Per una nuova epistemologia della pratica professionale. Bari.

Schön, Donald A. (1987/2006): Formare il professionista riflessivo. Per una nuova prospettiva della formazione e dell'apprendimento nelle professioni. Milano.

Sclavi, Marianella/Giornelli, Gabriella (eds.) (2014): La scuola e l'arte di ascoltare. Gli ingredienti delle scuole felici. Milano.

Scoth, Roberto (1980): La matematica negli istituti tecnici italiani. Analisi storica dei programmi d'insegnamento (1859-1891), preface by Livia Giacardi. Cagliari.

Scuola di Barbiana (1967): Lettera a una professoressa. Firenze.

Scurati, Cesare (1997): Pedagogia della scuola. Brescia.

Soldani, Simonetta (2016): Dall'assenza all'eccellenza. Gli studenti di Filosofia e Filologia (1859-1881). In: Dei, Adele (ed.): L'Istituto di Studi Superiori e la cultura umanistica a Firenze. Vol. 1. Pisa, pp. 15-109.

Striano, Maura (2001): La razionalità riflessiva nell'agire educativo. Napoli 
Tognon, Giuseppe (1990): Benedetto Croce alla Minerva. La politica scolastica italiana tra Caporetto e la marcia su Roma. Brescia.

Tomasi, Tina/Sistoli Paoli, Nella (1990): La Scuola Normale di Pisa dal 1813 al 1945. Cronache di un'istituzione. Pisa. Ulivieri, Simonetta (2006): La formazione degli insegnanti della Secondaria e l'esperienza della SSIS. In: Di Bello, Giulia (ed.): Formazione e società della conoscenza. Storie, teorie, professionalità. Conference proceedings (Florence, 9-10 November 2004). Firenze, pp. 41-58.

Ulivieri, Simonetta (2012): Corsi e ricorsi nella formazione degli insegnanti della Scuola Secondaria. Dalla SSIS al TFA. In: Ead. (ed.): Insegnare nella scuola secondaria. Per una declinazione della professionalità docente. Pisa, pp. $13-43$.

Villari, Pasquale (1889): Sull'istruzione secondaria classica. Notizie e documenti presentati al Parlamento nazionale dal Ministro della Pubblica Istruzione Paolo Boselli. Roma.

Villari, Pasquale (1891): Nuovi scritti pedagogici. Firenze.

Viñao, Antonio (2010): Les disciplines scolaires dans l'historiographie européenne. Angleterre, France, Espagne. In: Histoire de l'éducation 125, pp. 73-98. available online at http://histoire-education.revues.org/2111, 02.07.2020. Volpicelli, Ignazio (2003): Herbart e i suoi epigoni. Genesi e sviluppo di una filosofia dell'educazione. Torino. 